\title{
Building and Managing Your Brand
}

\author{
Robert J Kwortnik
}

Have you eaten at Zoup!, Smashburger, or Big Al's- Steaks? Have you stayed at Andaz, Aloft, or Element? If you haven't yet experienced one of these products, let alone heard of them, it's probably because they are brands that are still in the building process. Each of these brands is relatively new in their industry sector, but they may someday be as familiar as Taco Bell or Marriott. From Andaz to Zoup!, these companies were built with a simple but powerful promise to guests that they will receive specific benefits from patronizing that brand. Smashburger's promise, for instance, is to be "THE place for burger lovers... Where smash, sizzle, savor, means a dedication to creating the best-tasting 'cookedto-order' burger."

Building a brand is not a new idea, but the process has become increasingly sophisticated and supported by marketing research. This chapter helps you to think like a brand marketer. Even as an independent operator, you can borrow from the playbook of the established brands and take a strategic approach to brand building and management. If you do work for an established brand-or are thinking about affiliating with one, this chapter helps you to understand the importance of branding in a crowded marketplace. The approach to brand strategy I introduce in this chapter is derived in part from a course on Service Experience Management that I teach at Cornell University's School of Hotel Administration, as well as lessons I've learned while providing brand-strategy consulting to hotel companies, cruise lines, and tourism destinations. The centerpiece of the approach is a Process Framework for Strategic Branding that serves as a guide for diagnosing brand problems and opportunities and for building successful brand experiences.

\section{What is a Brand?}

A brand identity may include a name, logo, trade character (e.g., Ronald McDonald or a gecko), package design, or trade dress (including a color scheme and look of a building exterior). All of these are used to identify the product's owner and distinguish the product from competitors. Typically, these elements of a brand are legally protected as intellectual property through a trademark, which is registered with a government agency responsible for overseeing property rights (e.g., the U.S. Patent 
and Trademark Office). Creating a legal brand is important for your business, because the brand identifies you to consumers and protects both parties from product imitators. ${ }^{1}$

For hospitality companies, a strong brand can be one of the most valuable assets-because the brand provides value to customers, primarily by promising a uniform level of quality delivered by the brand. ${ }^{2}$ Customers use brands to make inferences about benefits offered based on knowledge about brand attributes (e.g., Ritz-Carlton Hotels and Resorts provide highly personalized service) and about brand associations (e.g., Ritz-Carlton is associated with luxury). Strong brands also possess top-of-themind awareness, so that when customers recall brands in a particular category (e.g., a luxury hotel chain) the brand automatically comes to mind (Ritz-Carlton). Such brand awareness is especially important for decisions where consumers may not have ready access to complete information about their available choices. In that case, consumers are likely to choose familiar brands. These are some of the reasons why owners of hospitality services looked to established brands as partners.

\section{The Brand-Affiliation Decision}

In some sections of the hospitality industry, affiliating with a brand versus going it alone as an independent operator is a pivotal strategic decision. In the lodging industry, it seems that brands are gaining increasing ascendancy, even though independent, single-location properties have long been the norm, as shown in hotel census data from the leading research firm, STR Global (see Table 25.1). ${ }^{3}$

Looking at the numbers, we see that branded hotel companies added nearly 4,700 properties $(+10.4$ percent) versus the addition of 1,587 independent properties (+2.2 percent). Growth was particularly strong in the Asia-Pacific region, where branded properties increased by 13.2 percent, and in the North American region, where branded properties increased by in North America, where two out of three rooms are managed by branded hotels. The growth in these regions from 2005 to 2010 occurred despite a net decrease in the number of brands due to bankruptcies, mergers, and buyouts (a drop of 4.6 percent to 636$)$. In the United States, the 10 largest hotel companies now either directly own or franchise more than half of lodging supply (see Table 25.2). ${ }^{4}$

Research indicates that there are financial benefits to brand affiliation. For one thing, brand affiliation increases a hotel property's market valuation. ${ }^{5}$ For another, a 2009 study by Ypartnership/Yankelovich found that four out of five leisure travelers prefer a brand-affiliated hotel. ${ }^{6}$ Additionally, STR analysis released in April 2009 reported that, in the United States, brand-affiliated hotels have outperformed independent properties for the past 15 years on occupancy, average daily rate (ADR), and revenue per available room (RevPAR). ${ }^{7}$ This trend continued through the first half of 
2010 (see Table 25.3). The same pattern of results holds for properties in the Asia- Pacific region, with brand affiliated hotels achieving 7.4 percent higher ADR and 7.2 percent higher RevPAR (occupancy differences are negligible). As discussed shortly, though, performance differs for hotels in Europe.

Table 25.1

STR Global Hotel Census Data (2005-2010)

\begin{tabular}{|c|c|c|c|c|c|c|c|c|c|}
\hline \multirow{2}{*}{$\begin{array}{l}\text { Region/ } \\
\text { Ownership }\end{array}$} & \multicolumn{3}{|c|}{ Brands } & \multicolumn{3}{|c|}{ Properties } & \multicolumn{3}{|c|}{ Rooms } \\
\hline & 2005 & 2010 & $\%+1-$ & 2005 & 2010 & $\%+1-$ & 2005 & 2010 & $\%+1-$ \\
\hline \multicolumn{10}{|l|}{ Asia-Pacific } \\
\hline Branded & 211 & 219 & $+0.5 \%$ & 4,106 & 4,647 & $+13.2 \%$ & 706,703 & 845,955 & $+19.7 \%$ \\
\hline Independent & & & & 10,525 & 11,052 & $+5.0 \%$ & $1,234,315$ & $1,315,436$ & $+6.6 \%$ \\
\hline Total & & & & 14,631 & 15,699 & $+7.3 \%$ & $1,941,018$ & $2,161,391$ & $+11.4 \%$ \\
\hline$\%$ Branded & & & & $28.1 \%$ & $29.6 \%$ & & $36.4 \%$ & $39.1 \%$ & \\
\hline \multicolumn{10}{|l|}{ Europe } \\
\hline Branded & 364 & 352 & $-3.2 \%$ & 13,397 & 13,488 & $+0.6 \%$ & $1,482,027$ & $1,566,106$ & $+5.7 \%$ \\
\hline Independent & & & & 31,819 & 32,926 & $+3.5 \%$ & $2,017,847$ & $2,109,928$ & $+4.6 \%$ \\
\hline Total & & & & 45,216 & 46,414 & $+2.6 \%$ & $3,499,874$ & $3,676,034$ & $+5.0 \%$ \\
\hline$\%$ Branded & & & & $29.6 \%$ & $29.1 \%$ & & $42.3 \%$ & $42.6 \%$ & \\
\hline \multicolumn{10}{|l|}{ North America } \\
\hline Branded & 272 & 267 & $-1.8 \%$ & 27,710 & 31,776 & $+14.7 \%$ & $3,244,780$ & $3,651,979$ & $+12.5 \%$ \\
\hline Independent & & & & 28,773 & 28,726 & $-0.2 \%$ & $1,756,927$ & $1,820,606$ & $+3.6 \%$ \\
\hline Total & & & & 56,483 & 60,502 & $+7.1 \%$ & $5,001,707$ & $5,472,585$ & $+9.4 \%$ \\
\hline$\%$ Branded & & & & $49.1 \%$ & $52.5 \%$ & & $64.9 \%$ & $66.7 \%$ & \\
\hline \multicolumn{10}{|l|}{ Total } \\
\hline Branded & 667 & 636 & $-4.6 \%$ & 45,213 & 49,911 & $+10.4 \%$ & $5,433,510$ & $6,064,040$ & $+11.6 \%$ \\
\hline Independent & & & & 71,117 & 72,704 & $+2.2 \%$ & $5,009,089$ & $5,245,970$ & $+4.7 \%$ \\
\hline Total & & & & 116,330 & 122,615 & $+5.4 \%$ & $10,442,599$ & $11,310,010$ & $+8.3 \%$ \\
\hline$\%$ Branded & & & & $38.9 \%$ & $40.7 \%$ & & $52.0 \%$ & $53.6 \%$ & \\
\hline
\end{tabular}

Note: Many brands are in multiple regions; each of these brands was counted only once.

Source: Author's analysis of STR Global lodging census data made available to the author May 12, 2010.

Table 25.2

The 10 Largest Hotel Companies in the World

\begin{tabular}{lccc}
\hline Company & \# Brands & \# Properties & \# Rooms \\
\hline InterContinental Hotels Group & 7 & 4,389 & 634,888 \\
Marriott International & 18 & 3,400 & 595,461 \\
Wyndham Worldwide & 11 & 7,090 & 593,300 \\
Hilton Hotels & 10 & 3,500 & 545,000 \\
Accor Group & 16 & 4,111 & 485,549 \\
Choice Hotels & 11 & 6,032 & 547,968 \\
Best Western & 1 & 4,032 & 308,428 \\
Starwood Hotels \& Resorts & 9 & 999 & 298,047 \\
Global Hyatt & 8 & 434 & 120,031 \\
Carlson (Rezidor Hotel Group) & 5 & 396 & 84,200 \\
\hline
\end{tabular}

Source: Author's analysis of lodging supply published on company Web sites or obtained from company media and public relations departments.

Allying with an established brand brings a number of advantages that contribute to improved financial performance, including access to consumer-tested marketing knowledge and tools, such as the brand Web site and reservation system, marketing communications programs, service standards and 
training programs, sales and marketing teams, and referral and loyalty programs. Branded hotels also frequently have an advantage in booking meetings, incentive, conference, and exhibition (MICE) business, which typically involve corporate accounts that are negotiated nationally. ${ }^{8}$

Table 25.3

STR Lodging Performance Metrics, United States and Asia/Pacific

\begin{tabular}{lccc}
\hline & Occupancy (\%) & ADR (US\$) & RevPAR (US\$) \\
\hline U.S. brand-affiliated & 57.7 & 98.35 & 56.80 \\
U.S. independent & 53.4 & 94.30 & 50.32 \\
Asia brand-affiliated & 63.9 & 128.37 & 82.04 \\
Asia independent & 64.1 & 118.82 & 76.16 \\
\hline
\end{tabular}

Source: STR Global Trend Statistics made available to the author on July 20, 2010.

Table 25.4

STR Lodging Performance Metrics, Europe

\begin{tabular}{lccc}
\hline & Occupancy (\%) & ADR (Euro) & RevPAR (Euro) \\
\hline Europe brand-affiliated & 61.2 & 93.49 & 57.18 \\
Europe Independent & 58.3 & 118.96 & 69.35 \\
\hline
\end{tabular}

Source: STR Global Trend Statistics made available to the author on July 20, 2010.

Perhaps the biggest benefit of brand affiliation is access to the customer-based brand equitythe brand awareness, loyalty, perceptions of quality, and beliefs about the brand. ${ }^{9}$ Thanks to brand standards and marketing, consumers perceive-and seek out - the consistency and reduced purchase risk that a brand provides. This is why automobile travelers who see the Golden Arches in the distance are apt to choose McDonald's for a meal over a local independent diner, even though the latter may provide better food. Such uncertainty reduction is especially important for the transient market, where hotels make the bulk of their profits. ${ }^{10}$

Despite all those benefits of affiliating with an established brand, for many hotel owners in much of the world, independent operation works well. The STR lodging census also reveals that approximately 70 percent of hotels and 60 percent of rooms in Europe and Asia are not brand-chain affiliated. Furthermore, STR metrics covering Europe (as of June 30, 2010) shows that although brandaffiliated hotels achieved higher occupancy rates (4.7\%), independent hotels earned much higher ADRs (21.4\%) and RevPAR (17.5\%); see Table 25.4. This is also true in some parts of the United States, where independent properties outperform brand-affiliated hotels in certain regional or local markets. ${ }^{11}$ 
One reason that hoteliers operate independently is the expense of brand affiliation. HVS International reported in 2009 that lodging franchise fees are often the second-largest operating expense (after payroll), typically averaging around 9 to 10 percent of total room revenue. ${ }^{12}$ In addition to royalties and system expenses, franchisees usually support the costs for upgrades to the brand, such as enhanced room amenities, bedding, and technology. For example, much of the cost of the billiondollar Holiday Inn brand relaunch, started in 2007 by Intercontinental Hotels Group, will be borne by the owners of the 3,300 properties, to cover new signs, marketing, and service and property upgrades. ${ }^{13}$ Beyond that, if you chafe at the prospect of being forced to use the brand's management systems and to be held accountable for brand standards, you may prefer independent operation.

Independent operation is also appropriate for hotels that operate in particular markets, for example, where guests desire boutique lodging or where traffic would support a small independent operation. Independent operation is also supported by the growing availability of low-cost Web applications or third-party systems that provide hotel owners with reservations and revenue management systems. With all of these considerations, your decision of whether to affiliate with a brand involves your own business strategy, which requires an analysis of the marketing environment and return on investment. Table 25.5 summarizes the main benefits and drawbacks of brand affiliation and independence.

\section{Going Independent-Building Your Brand}

In the rest of this chapter, I assume that you are going independent. While brand building involves creativity, it's primarily an analytic process that depends on data-driven decisions and the alignment of key stakeholders. Fundamental to this alignment is the articulation of a clear brand promise that attracts customers and provides a call to action. The importance of this brand promise cannot be overstated-the promise is the essence of both your value proposition to customers and the motivation for employees to live the brand. Let's examine this process and see examples of hospitality firms that have successfully implemented brand strategies.

As reflected in the Process Framework for Strategic Branding (Figure 25.1), building your brand starts with a research-based audit of customers' purchase motivations, your firm's competencies and systems, and your competitors' activities. As a brand strategist, once you determine how the brand experience addresses customers' needs and wants, you then can determine the core elements of the brand that your firm can efficiently provide; articulating a brand promise that demonstrates value; and 
selecting brand touch points, which are the tangible and experiential cues used in marketing communications to help consumers develop meanings about the brand.

Table 25.5

Brand Affiliation in the Hospitality Industry: Benefits and Drawbacks

Benefits

- Access to an established brand's equity-customer awareness of the brand, beliefs and knowledge about the brand, familiarity and comfort with the brand, perceptions of brand quality and value, trust in the brand, and loyalty to the brand

- Recognizable brand symbols, trade dress, and imagery

- Perceived consistency of brand environment, attributes, and service

- Market power derived from brand size and networks

- Efficiency and strength of one-stop marketing managementbrand Web site, sales support, central reservations system, revenue management system, marketing communications programs, and loyalty programs

- Established service training programs and standards

- Advantage is booking MICE business

- Positive effects on financial market valuation of the property

- Generally better performance on financial metrics (occupancy, $\mathrm{ADR}$, and RevPAR) depending on market location

Drawbacks

- Costly brand-affiliation (franchise) fees that average 9 to $10 \%$ of room revenue, including revenue-based royalty fees, payments for joint advertising, and fees for bookings made through the brand's CRS

- Risk of being deflagged and losing franchise fees for failure to uphold brand standards

- Strict franchise contracts

- Required payment for brand upgrades (e.g., property renovations or new brand signs)

- Loss of some financial and operational control to brand franchisor

- Reduced ability to be entrepreneurial

- Required adherence to management approaches, training, pricing systems, brand standards, and brand symbols

- Loss of individual business identity subsumed by the brand

- Greater time required for reporting of operational performance to corporate

- Uncertain financial returns to brand affiliation depending upon market location 


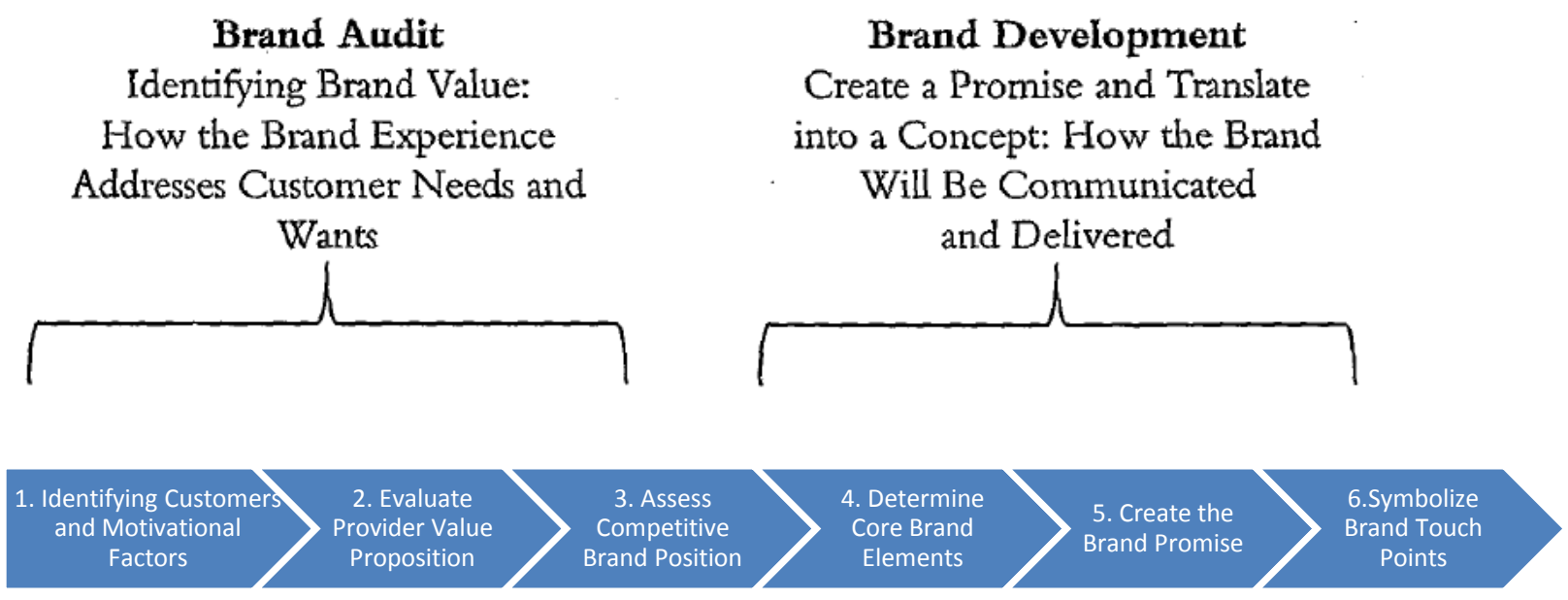

Step 1: Identify Customers and Their Motivational Factors

Start developing your brand strategy by talking with your existing and (carefully chosen) potential customers. Have a type (or types) of customer in mind as you develop your brand. For example, as part of a destination-branding project, a team of Cornell University graduate students that I supervised used tourism data from a variety of sources to determine current source markets for visitors to the African nation of Zambia. Next, the team performed a demographic and psychographic (lifestyle) analysis to map the types of travelers with the financial means for and personal interest in a Zambia tourism experience. This analysis produced a type of target visitor-relatively affluent, well educated, avid travelers from the United States and the United Kingdom.

Although a good start, the customer picture was incomplete because it lacked a description of purchase motivations - that is, the reasons why one would travel to Zambia. Developing a brand requires a rich understanding of what motivates consumers to buy from certain product categories-to tap into the "Whys for Buys." ${ }^{14}$ Direct questions about purchase motivations often yield purely rational explanations-when in fact the decision may be largely emotional or influenced by self-relevant motives. ${ }^{15} \mathrm{~A}$ better approach is to use indirect methods to evoke customers' motivations, such as depth interviews and focus groups, analysis of online forums where consumers talk about their product experiences, and surveys that use indirect questioning and interpretive analysis of consumer responses. So an effective question might be, "Tell me about the best vacation experience you've had recently and what made it special?"16

Determining consumers' underlying purchase motivations early in the strategic branding process will yield significant dividends later. This is because you can translate consumers' "whys for buys" into 
brand elements that are the foundation of the brand promise. Moreover, using a data-driven approach helps to ensure that decision makers hear the voice of the customer and don't impose assumptions and personal preferences on the prospective market.

A classic excellent example of such fact-based brand building is Marriott International's development of the Courtyard by Marriott brand in the early 1980s. ${ }^{17}$ The original idea for Courtyard was to create a smaller version of the typical Marriott hotel. However, rather than rely on management assumptions, Marriott hired consultants who used sophisticated statistical approaches to extract a set of hotel features that would provide the most value to the target market of price-sensitive frequent business travelers and occasional leisure travelers. In addition to hotel design and room-amenity preferences, the research revealed that customers sought a hotel with personality that was informal, quiet, relaxing, and charming. These benefits became the foundation of the Courtyard brand when it was launched as "a special little hotel at a very comfortable price."

With Courtyard's success, Marriott kept the customer-listening system attuned to the market and the brand evolved as customer preferences changed. For example, in the early 2000s, Marriott again used a research-based approach to develop a reinvention and renovation program, in part to stave off the fast-growing Hilton Garden Inn brand. ${ }^{18}$ The hotel design had to support the brand identity, which had evolved to "exactly the room they need, no more, no less," and which was articulated by the brand slogan, "The Room that Works." Ongoing brand redesign in 2010 focused on a new lobby concept that featured an open-access front desk, casual meeting spaces, flexible work areas, a bistro, and a touch-screen virtual concierge. These brand "touch points" symbolize the new Courtyard brand message, "It's a New Stay." As you can see from Marriott's experience, brand building is a continuous process that demands rigorous analysis of customer markets and a fact-based approach to brand design.

\section{Step 2: Evaluate Your Value Proposition}

Although your brand's value resides in the minds of customers, to deliver on your brand promise you must determine the sources of this value with a thorough and objective assessment of how you deliver your guests' desired services. In addition to the information about your target markets' needs, wants, and motivations gleaned from the customer analysis in Step 1, assessment of the value proposition must examine customers' expectations and their perceptions of product performance relative to those expectations.

Comment cards and customer surveys will give you some of this information, but ratings alone are incomplete. Web comments will give you insights-particularly from travel review sites (e.g., 
TripAdvisor.com.) and online discussion forums where consumers describe their expectations, their experiences, and what they think about it. Another source for information about expectations is your firm's marketing communications, such as advertising, sales materials, and Web site, which show your brand promise. Furthermore, you should scan published reports, travel guides, and expert reviews that may also influence consumers' expectations.

Even a good service experience may be perceived poorly if the customers expected something different. For example, with a service operations colleague, I conducted a study of a cruise line's onboard dining experience. ${ }^{19} \mathrm{~A}$ key brand promise for this cruise line was complete freedom of choice for onboard dining, which was compelling to customers who were not attracted to the typical cruise's structured itineraries. Such a promise is particularly unusual for a cruise ship catering to 2,500 or more guests. As you can guess, though, delivering on this promise presented significant operating challenges. Not surprisingly, allowing for freedom of choice meant that queues were common during peak dining times, some restaurants were underutilized early in the cruise, and others were inaccessible to guests later in the cruise. The cruise line attempted several fixes, such as a reservations system (which, arguably, countered the free-choice promise) and guides posted in public areas who showed which restaurants were available and which ones were full or had waits. Still, customer ratings showed that guests too often rated the dining experience negatively. Our analysis indicated, though, that customer dissatisfaction was as much a function of high expectations set by brand marketing as it was of inadequate performance.

Brand management depends on service experience management before, during, and after the actual service. Customer expectations become a part of the service, which is why value is actually cocreated by the customer and hospitality provider. ${ }^{20}$ Thus, analysis of the value proposition must address both the firm's sources of value (e.g., physical service environment, the service provided by employees, and processes by which service is delivered), and also the customer's input to value co-creation, such as service expectations, price paid for service, and the effort and actions required of customers for service delivery. By evaluating these dimensions, you can help to ensure that brand messaging is consistent with the promised experience.

\section{Step 3: Assess Competitive Brand Positions}

Customers are comparing your brand's value to that of competitive brands. To differentiate from your competition, you must ascertain key competitors' value propositions. Points of differentiation between your brand and those of competitors may be specific features or a focus on different 
experiences. To begin this assessment, you need look no further than competitors' Web sites and marketing communications, which typically highlight what aspects of the brand its marketers feel contribute most to customer value. What you're looking for is competitive weaknesses along dimensions that your customer research shows are important for motivating purchase-what I call positioning points. These positioning points must matter to customers. You need to identify some distinctive aspect of the product, such as a design, technology, service, or a combination of these factors that customers value and that are aligned with the brand.

Returning to the Zambia study, when my students conducted a positioning assessment of African destinations that attracted the same tourism markets as Zambia, they charted the other nation's brand slogans and symbols. They found the following: Botswana: Opportunity and Tranquility; Kenya: The Magic of Africa; South Africa: It's Possible; and Tanzania: Land of Kilimanjaro and Zanzibar. Next, the team analyzed each country's positioning points, such as destination attractions and experiences. The team also analyzed travel Web sites and discussion forums to see what visitors were saying were the must-see and must-do aspects of each destination, as well as the weaknesses (e.g., crime, poverty, poor infrastructure, or high costs).

With this detailed analysis, we gained greater clarity of Zambia's competitive position. A key attraction for Zambia is Victoria Falls, on the border with Zimbabwe. The fact that Zimbabwe has experienced economic and political problems creates an opportunity for Zambia. Zambia also possesses huge national parks that permit unspoiled and relatively uncrowded game viewing, unlike some competitors with busier and more commercialized safari operations. Zambia is English speaking and politically stable, has little crime, and is known for friendly people-attributes that facilitate a close interaction between visitors and the local culture. Aligned with traveler motivations, these positioning points are the core elements for Zambia's customer- based brand strategy.

A useful way to visualize competitive brand positioning is to create a brand hierarchy that summarizes the brand-the promise, elements, and touch points-for each competitor (see Figure 25.2). A brand hierarchy can reveal areas where a brand enjoys a differential advantage and should be actively promoted. Let's look at the specifics of the brand hierarchy as a tool for conceptualizing brand strategy.

Step 4: Develop Core Brand Elements

As discussed in Step 1, the foundation of a brand promise is your customers' needs, wants, and motivations that most influence customer choice. In the Process Framework for Strategic Branding, 
these motivations are translated into core brand elements, which provide meaning and connect the customer to the brand. Brand elements should speak to why customers select a hospitality service and specific provider, what they seek from the experience, and what the brand promises to deliver. Solid and compelling brand elements are derived from your brand audit and represent the mapping of customer motivations to the services and experiences that you provide.

For example, since the mid-1970s, management of Carnival Cruise Lines has positioned the brand based on the simple promise of a fun ship experience, a contrast to existing cruise lines. ${ }^{21}$ Instead of formal, upscale experiences, Carnival offered cruisers a party at sea with late nights, dancing, drinking, and gaming. Even though Carnival has toned down the activity over the years (aiming to attract families), the "fun ships" promise still rests on such brand elements as fun, excitement, and novelty. These are emotional and experiential benefits that motivate Carnival's customers to choose the brand (see Figure 25.2), and Carnival clearly delivers those benefits. From the design of the ships, with their "entertainment architecture," to the messages in online and television ads (including talking towel animals or shrieking adults flying down a water slide), every brand symbol suggests (shouts!) fun. Thus, the customers' motivations are well aligned with the brand's core elements.

Figure 25.2

Brand Development Hierarchy

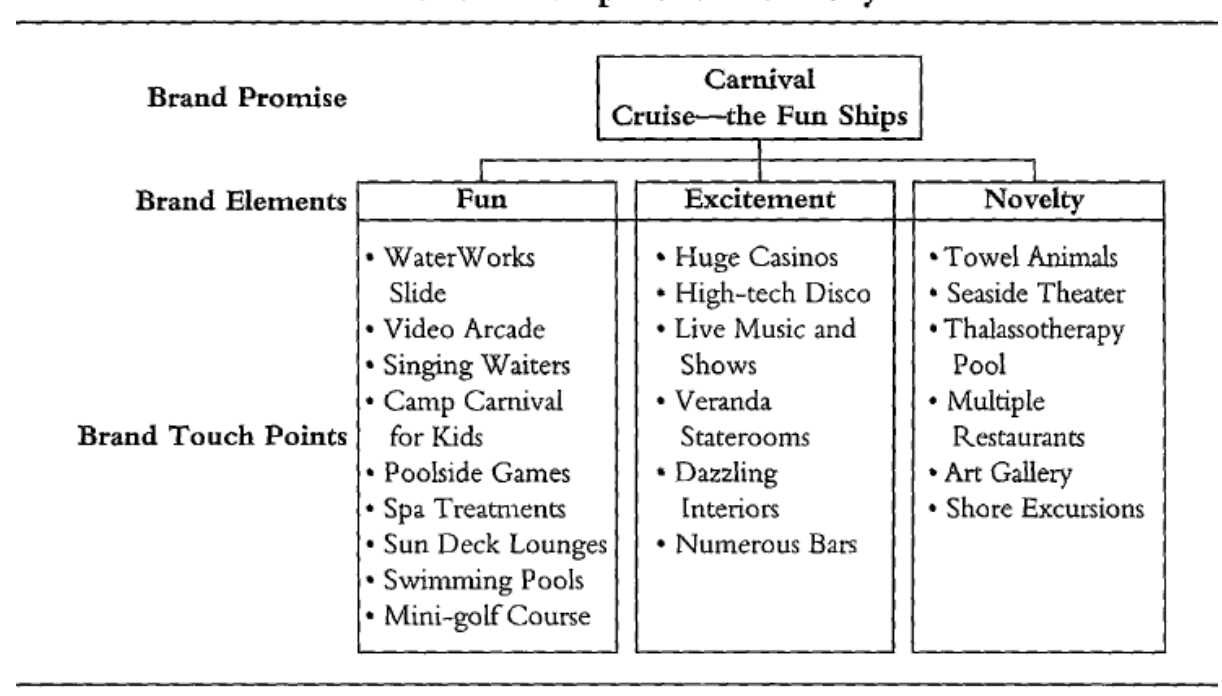

If listening systems used in Step 1 of the process are well attuned to the market, brand elements should be readily evident. However, in some cases, you might have to categorize your customers' motivations to reveal brand elements. The reason for this is that brand elements need to be communicated at a level that encompasses enough of a range of related reasons for purchase, but not at such a high level that they lose meaning. Individual motivations for travel are remarkably diverse and 
nuanced. For instance, some Carnival customers might say they want to meet new people and see new places, whereas others might say they want to escape their ordinary day-to-day routines to experience fantastic environments and wild activities. But that's all still fun.

Here's why you must link motivations to the brand through the brand elements. First, brand elements form the plot points for brand communications - the messages and imagery that create a dialogue with consumers. Second, clarity of brand elements helps to ground the brand promise by focusing it on the customer (i.e., basing it on customer motivations), and ensuring that it is firm specific (i.e., aligned with what your organization can efficiently and effectively provide). So, the Carnival Cruise Lines promise of a "fun ship" experience is based on the customers' desire for fun, excitement, and novelty, and the firm's continuing efforts to produce ships, services, and itineraries that are aligned with these brand elements.

\section{Step 5: Build a Brand Promise}

The brand promise, which guides your management of the brand, is developed from the four preceding steps. I want to emphasize that development of the promise is a "bottom-up" process, based on brand elements. The brand promise conveys the experience that a customer desires and a hospitality firm intends to deliver. The promise should spark a positive reaction, which means it must be succinct and compelling. Some brand promises also serve as slogans used in marketing communications, as in the case of the famous slogan developed for the Las Vegas Convention and Visitors Authority. Analyzing Vegas's successful "What happens here stays here" theme, the account director of the agency that created the campaign, said: " . . if you can't boil down your brand to three words, you're not trying hard enough." ${ }^{22}$ For Las Vegas, the brand strategy team boiled the experience down to the concept of adult freedom. The account director further explained:

Your brand is not simply your ad campaign, rather the campaign is the articulation of the brand. [For Las Vegas] we needed something that not only conveyed "adult freedom," but actually encouraged it. Something that gave consumers permission to enjoy themselves in a way they don't do elsewhere. The "What Happens Here" campaign became the means of delivering the brand message and reflecting the Las Vegas experience.

Another notable example of a powerful brand promise comes from the Recreational Boating \& Fishing Foundation, which developed a "Take Me Fishing" brand to promote boating and fishing as a means to bring families together and to encourage environmental stewardship of aquatic resources. One print advertisement shows a father and daughter fishing from a boat; the ad's text says, "Take me 
fishing, because I get the giggles when the boat bounces. Take me fishing, you can think about work later. Take me fishing, and show me that worms really aren't that icky. Take me fishing, because my wedding will be sooner than you think." The message makes the subtle promise that the activity of recreational boating and fishing will create a lasting bond between father and daughter-a self-relevant outcome with a strong emotional appeal to most any parent.

Arriving at an encompassing and memorable brand promise requires more than just a catchy slogan. Many companies struggle to articulate what their brand is-but if it's hard for brand managers to put the promise into words, it will be even more difficult for customers, employees, and other key stakeholders to "get" the brand. Brand ambiguity creates additional problems down the road as brand marketers try to communicate the brand or as product developers have to make decisions about new features or services that are consistent with the brand. So, whatever you do, make sure your brand promise is clear.

The best brand promises work because they resonate with customers and are true to the brand. For example, Costa Rica's "No artificial ingredients" tourism slogan promises an environmentally friendly beach-and-nature vacation experience. Not only is this what travelers to Costa Rica seek, but the country is also well positioned to provide that experience. Royal Caribbean Cruise Line's award winning brand slogan "Get Out There" symbolized the brand's active-adventure cruise experience. Its new slogan, "The Nation of Why Not," continues the same theme, with such touch points as an onboard rock-climbing wall, zip line, and similar extreme-sports activities.

By contrast, if you pick a vague or otherwise ill-considered slogan, you can interfere with your customers' satisfaction, even if your operation is running well. I saw this in a small hotel chain in Europe, which used the brand promise, "A remarkable stay sure to exceed your expectations." Not only was this promise vague, but it also sets the service bar so high that it is nearly impossible to meet.

\section{Step 6: Select Salient Brand Touch Points}

Your final step in the process of strategic brand development is to select salient brand touch points that symbolize the brand promise and elements. These are aspects of the brand that your customer can sense or touch to determine the brand's meaning and imagine how a service will deliver a certain experience. I just mentioned the $\mathrm{RCl}$ touch points, and Carnival Cruise Lines touch points symbolize fun (including singing waiters and the water slides), excitement (brightly colored interiors and large casinos), and novelty (the towel animals and theme restaurants). 
An excellent example of a hotel company that selected bold touch points to symbolize the brand is W Hotels. W's target market is the hip influential - the trendsetters (or people who like to feel that they are trendsetters). W starts with an edgy brand promise: a "Wow" experience for the "ultimate insider." W's brand marketing intends to evoke impressions of the chic life, though with sensibility. That is, $\mathrm{W}$ offers style, but also substance-cutting-edge design combined with the service and amenities expected from an upscale hotel chain. As a lifestyle brand, W offers "contemporary restaurant concepts, glamorous nightlife experiences, stylish retail concepts, and signature spas." Even the W language used in the service promise, "Whatever/ Whenever" (with the play on the W letter) serves as a brand touch point in support of the Wow! promise: "Birthday Party at 35,000 Feet? Bathtub of Hot Chocolate? At W Hotels, your wish truly is our command with our Whatever/Whenever service. Whatever you want (as long as it's legal!)."

\section{Brand Testing and Monitoring}

Finally, you must test your new brand concept or any changes you are making to your existing brand to ensure that the brand hierarchy is relevant and resonant. For example, my students created brand hierarchies for several potential brand promises for Zambia. These concepts were then tested using presentations to the country's tourism officials and suppliers, allowing plenty of feedback opportunities, and an online survey test with more than 500 past and potential visitors to the country. Data from these tests were used to aid the country's tourism leaders in their determination of the final brand.

Testing a brand concept with employees, intermediaries, management, and customers can help align stakeholders by establishing a transparent, fact-based filtering process. It also can reduce chances of promoting a brand that fails to motivate employees or customers-or worse, that creates a negative image. Our Zambia study found that the nation had inadvertently done this with an earlier slogan, "The Real Africa." The intended promise was that visitors could have an authentic African experience in Zambia. Unfortunately, however, the team's study revealed that the Real Africa brand invoked negative imagery related to warfare, disease, poverty, and crime. So when you choose any slogan, test it carefully for unintended meanings. You can minimize the risk of weak or negative communication by affiliating with an established brand, but you can also use the Process Framework for Strategic Branding to guide you in building brand equity.

Data-driven strategic branding applies not only to building of new brands, but also to relaunching or refreshing existing brands, and to brand reviews. All brands-even highly successful 
ones-should be put through the process of strategic branding to ensure that the brand still connects with customers. Consumer needs and wants are dynamic. Competitors change and introduce new products to develop new markets, to satisfy unmet needs of existing markets, or to take market share from firms that have a hold on profitable customers. A brand that rests on past successes is likely to go the way of Oldsmobile; - a bygone brand emptied of brand equity. Compare that failure to the 2007 brand relaunch of the 60-plus-year-old Holiday Inn brand, for which their brand strategists boast: "We're changing a good deal of things. But we're not changing the fact that we're a good deal." A comparison of prices for rebranded Holiday Inn properties relative to properties that have yet to receive the brand upgrade shows a price premium for the "refreshed" properties-a brand-driven boost to the bottom line that any owner will find similarly refreshing.

\footnotetext{
${ }^{1}$ See D. A. Aaker, Managing Brand Equity (New York: Free Press, 1991).

${ }^{2}$ K. L. Keller and D. R. Lehmann, "How do brands create value?" Marketing Management 12(3) (2003): 26-40.

${ }^{3}$ STR Global, Hotel Data Set, 2010.

${ }^{4}$ A. Kalnins, "Markets: The U.S. Lodging Industry," Journal of Economic Perspectives 20 (Fall 2006): 203-218.

${ }^{5}$ J. W. O'Neill and Q. Xiao, "The Role of Brand Affiliation in Hotel Market Value," Cornell Hotel and Restaurant Administration Quarterly 47'(3) (2006): 210-223.

${ }^{6}$ Ypartnership/Yankelovich, National Travel Monitor, www.hospitalitynet.org/news/4042580.search?query=national+travel+monitor, seen on May 15, 2010.

${ }^{7}$ C. Church, "Independent Supply, Demand Growth Closer to Brands after 2001," HotelNewsNow.com, www.hotelnewsnow.com/Articleprint.aspxPArticleld=953\&print=true, seen July 19, 2010.

${ }^{8}$ Kalnins, 2006.

${ }^{9}$ Aaker, 1991.

${ }^{10}$ Kalnins, 2006.

${ }^{11}$ Church, 2009.

${ }^{12}$ S. Rushmore, K. Fitzpatrick, and T. Lam. 2009 U.S. Hotel Franchise Fee Guide (Mineola, NY: HVS, 2009).

${ }^{13}$ www.hotel-online.com/News/PR2007_4th/Oct07_HIRelaunch.html, seen on May 13, 2010.

${ }^{14}$ S.J. Levy, "Symbols for Sale," Harvard Business Review. 37(4) (1959): 117-124.

${ }^{15}$ See R. J. Kwortnik and W. T. Ross, "The Role of Positive Emotions in Experiential Decisions, International Journal of Research in Marketing 24 (December 2007).

${ }^{16}$ Compare R.J. Kwortnik, "Clarifying Fuzzy Hospitality-Management Problems with Depth Interviews and Qualitative Analysis," Cornell Hotel and Restaurant Administration Quarterly AA (April 2003): 117-129; and B. Wansink, "Using Laddering to Understand and Leverage a Brand's Equity," Qualitative Market Research, 6(3) (2003): 111-118.

17 J. Wind, P. E. Green, D. Shifflet, and M. Scarbrough, "Courtyard by Marriott: Designing a Hotel Facility with Consumer-Based Marketing Models," Interfaces 19(1) (1989): 25-47.

${ }^{18}$ C. Lambert, Guest lecture at Cornell University, October 3, 2002.

${ }^{19}$ R. J. Kwortnik and G. M. Thompson, "Unifying Service Marketing and Operations with Service Experience Management," Journal of Service Research 11(4) (2009): 389-406.

${ }^{20}$ S. L. Vargo and R. F. Lusch, "Evolving to a New Dominant Logic for Marketing," Journal of Marketing 68 (January 2004): 1-17.

${ }^{21}$ R. J. Kwortnik, "Carnival Cruise Lines: Burnishing the Brand," Cornell Hotel and Restaurant Administration Quarterly Al (August 2006): 286-300.

${ }^{22}$ R. O' Keefe, "What Happens Here Stays Here Story," Travel Marketing Decisions 9 (Fall 2007): 4.
} 